EWA JANISZEWSKA ${ }^{1}$ (1) https://orcid.org/0000-0003-0221-7177

DOMINIKA PLUTA ${ }^{1}$ [D https://orcid.org/0000-0001-6246-9566

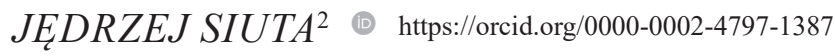

TADEUSZ DOBOSZ ${ }^{1}$ (1) https://orcid.org/0000-0003-0413-9109

${ }^{1}$ Zakład Technik Molekularnych Katedry Medycyny Sądowej Uniwersytetu Medycznego we Wrocławiu

${ }^{2}$ Zakład Medycyny Sądowej Katedry Medycyny Sądowej Uniwersytetu Medycznego we Wrocławiu

\title{
Muzealnictwo: nowoczesne technologie w stużbie historii. Część druga: Mokre preparaty muzealne jako źródło nowych informacji o przeszłości
}

\section{ABSTRACT}

Museology: modern technologies in service of history. Part 2: Formaldehyde preparations as a source of new information about the past

The history of medicine presented in the source literature is not particularly interesting for today's young adolescents. Showing it in a more practical and tangible way brings an excellent opportunity to spread historical knowledge. Medical museum studies - a specialist and still developing domain - serves this purpose very well. The results of scientific research performed before World War II - which do not meet ethical standards from today's point of view - explored the nature of different pathologies of human body, and were preserved as formaldehyde preparations and stored in medical museums. The scientific progress in molecular biology which allows scientists to conduct genetic research of old and decayed exhibits, gives them a chance to explore mysteries of diseases and evolution of pathogens, essential to verify historical data. 
Keywords: medical museum science, forensic medicine, molecular biology

Słowa kluczowe: muzealnictwo medyczne, medycyna sądowa, biologia molekularna

\section{Muzeum Medycyny Sądowej we Wroclawiu}

Wrocławskie Muzeum Medycyny Sądowej powstało najprawdopodobniej równolegle z Katedrą Medycyny Sądowej w 1887 roku w ramach ówczesnego Uniwersytetu Leopolda. Katedra zmieniła później nazwę na Institut für gerichtliche Medizin und Naturwissenschaftliche Kryminalistik. Zachowane do dziś zbiory muzealne pochodzą przede wszystkim z okresu 1908-1945. Kilka lat po wojnie do zasobów instytucji dołączono preparaty znalezione w Ząbkowicach Śląskich, prawdopodobnie pozostałość po Muzeum Traumatologii (ewakuowanym przez Niemców z Berlina) ${ }^{1}$. W 2017 roku do wrocławskiej placówki przekazano w depozyt ponad dwie tony eksponatów z likwidowanego magazynu muzealnego, który mieścił się na terenie Collegium Medicum Uniwersytetu Jagiellońskiego w Krakowie. Tym samym pod względem liczby eksponatów wrocławskie Muzeum stało się największym tego typu ośrodkiem w Polsce. Najliczniejszą grupę zgromadzonych muzealiów stanowią preparaty mokre, prezentujące zarówno anomalie anatomiczne, jak i zmiany urazowe, w tym powstałe na skutek działań samobójczych lub przestępczych, np.: rany kłute, rąbane, tłuczone, postrzałowe czy zatrucia. Wśród wymienionych eksponatów znajdują się także m.in. tatuaże więzienne, błony dziewicze różnego typu, narządy rozrodcze żeńskie uszkodzone przez działania przestępcze lub usuwanie niechcianych ciąż, zdeformowane płody na różnych etapach rozwoju, ślady żerowania zwierząt na ludzkim ciele, jak również uszkodzenia tkanek na skutek działania innych czynników mechanicznych, termicznych czy elektrycznych. Kolekcja jest unikatowa ze względu na charakter uwiecznionych patologii oraz fakt, iż współcześnie nie można pozyskiwać tego typu materiału w związku $\mathrm{z}$ rozbudowanymi zasadami bioetyki ${ }^{2}$. Wymienione narządy czy też fragmenty ciała umieszczone są w specjalnych naczyniach, wypełnionych odpowiednim płynem konserwującym. Dzięki temu zabiegowi preparaty zachowały się w doskonałym stanie mimo znacznego upływu czasu.

${ }^{1}$ Medycyna Uniwersytecka we Wrocławiu. Zarys historii od 1945 roku, Wrocław 2011, s. 58-61; A. Krzywobłocki, Dziesięć lat pracy konserwatorskiej w wojew. wrocławskim, „Ochrona Zabytków” 1955 , nr 8(1), 28, s. 50-57.

${ }^{2}$ Ustawa z dnia 1 lipca 2005 r., o pobieraniu, przechowywaniu i przeszczepianiu komórek, tkanek i narządów; Rozporządzenie Ministra Zdrowia z dnia 30 lipca 2009 r. w sprawie trybu i warunków przekazywania zwłok do celów naukowych. 


\section{Konserwacja tkanek dawniej i dziś}

Pierwsze efektywne próby preparacji i utrwalania tkanek ludzkich nastąpiły w XIX wieku ${ }^{3}$. Pionierem technik konserwacji był Frederik Ruysch, holenderski anatom i lekarz. Opracował on liquor balsamicus - mieszaninę cynobru, tlenku rtęci, siarczków i owczego tłuszczu. Roztwór wstrzykiwano do naczyń preparowanej tkanki, która miała być później przechowywana. Okazało się jednak, że mikstura szybko traci swoje właściwości i ulega wypłukaniu ${ }^{4}$. Obecnie najczęściej stosowane płyny utrwalające to formalina, glicerol oraz etanol. Ich zaletami jest skuteczne zachowanie morfologii preparatu, jednak większość ingeruje w struktury kwasu deoksyrybonukleinowego (DNA), negatywnie wpływając na jego stabilność. Aldehyd mrówkowy, inaczej formalina, w stężeniach $1 \%$ to roztwór dobrze penetrujący tkanki. Do jego zalet zalicza się zachowanie morfologii preparatu oraz niską cenę. Główną wadą jest tendencja do polimeryzacji DNA. Aby ten niekorzystny rezultat zmniejszyć, często miesza się go z etanolem ${ }^{5}$. Materiał genetyczny zawarty w roztworach formalinowych ulega silnej hydrolizie i sieciowaniu, przez co dochodzi do uszkodzeń i destabilizacji. Glicerol używany jest ze względu na nietoksyczne właściwości i niską lotność dzięki temu dobrze konserwuje preparaty, nawet przy ich rzadkim doglądaniu. Kolejny - etanol, penetruje tkanki podobnie jak formalina. W odróżnieniu od niej alkohol ma nieco mniejsze właściwości utwardzające tkankę, za to silniejsze wybielające. Wykazuje zdolności odwodnienia tkanek przy stężeniu 60\%, jednak częściej stosuje się roztwór 70\%. Powszechnie uważa się, że jest stosunkowo przyjazny dla DNA, lecz preparaty utrwalone za jego pomocą są mniej elastyczne 6 . Rzadziej stosowanym roztworem jest płyn, w skład którego wchodzą: alkohol absolutny (60\% mieszaniny), chloroform (30\% mieszaniny) i lodowaty kwas octowy (10\%). W porównaniu z większością omawianych wcześniej płynów w niewielkim stopniu (pominąwszy fragmentację) wpływa na strukturę DNA, nie niszcząc praktycznie RNA (kwasu rybonukleinowego). Zachowuje także morfologię tkanek oraz epitopy antygenowe - cząsteczki niezbędne do prowadzenia reakcji immunohistochemicznych (przydatnych m.in. w diagnostyce chorób nowotworowych) ${ }^{7}$. Jest więc on dobrą alternatywą dla formaliny. W wypadkach, w których zachował się nieoczekiwanie oryginalny, żywy kolor tkanki, próbki płynu są obecnie analizowane z nadzieją na dokonanie postępu w jakości konserwacji. Mokre preparaty wymagają okresowego sprawdzania stanu płynów konserwujących oraz ich wymiany bądź uzupełnienia. Jest to bardzo ważne, aby nie dopuścić do zniszczenia tych unikatowych zbiorów. Wiele eksponatów Muzeum Medycyny Sądowej należało rekonserwować - uzupełnić płyn lub wymienić go na świeży, uszczelnić naczynie itp. Profesor Tadeusz Dobosz, kierownik Zakładu Technik

${ }^{3}$ R.W. Gryglewski, Zygmunt Laskowski i jego technika tworzenia preparatów anatomicznych, „Przegląd Lekarski” 2015, nr 72, s. 707.

${ }^{4}$ K. Wilemska, M. Zieliński, M. Jasińska, M. Szynawa, M. Kucharzewski, Frederik Ruysch-̇̇ycie i działalność medyczna, „Annales Academiae Medicae Silesiensis” 2012, nr 66, s. 91-92.

${ }_{5}^{5}$ Podręczny stownik chemiczny, red. R. Hassa, J. Mrzigod, Katowice 2004, s. 135.

${ }^{6}$ M. Hildebrand, Anatomical preparations, Berkley, California, 1968, s. 7-8.

${ }^{7}$ A. Korga, Trudności w wykorzystaniu tkanek $z$ archiwalnych bloczków parafinowych $w$ badaniach ekspresji RNA, „Postępy Higieny i Medycyny Doświadczalnej” 2007, nr 61, s. 151-154. 
Molekularnych i opiekun Muzeum, nadał tym zwykle mało cenionym czynnościom duży walor dydaktyczny. Studentom kierunku lekarskiego zaproponowano pierwsze w Polsce zajęcia fakultatywne z muzealnictwa medycznego ${ }^{8}$. Muzealnictwo medyczne jest też dostępne dla studentów zagranicznych uczelni, którzy przyjeżdżają do Wrocławia w ramach IFMSA (Międzynarodowa Federacja Stowarzyszeń Studentów Medycyny, ang. Federation of Medical Students' Association). Mają oni okazję rekonserwować eksponaty wrocławskiego Muzeum podczas Letniej Szkoły Konserwacji Muzealnej. Jest to doskonały pomysł na przekazanie wiedzy dotyczącej konserwacji tego typu muzealiów (którą niewielu muzealników potrafi w sposób właściwy przeprowadzić), ale także niebywała pomoc w ratowaniu tak licznej i niezwykłej kolekcji. Część studentów interesuje się dalej muzealnictwem po powrocie do macierzystych krajów, o czym świadczą ich - czasami bardzo szczegółowe - zapytania.

\section{Płyn konserwujący - nowe źródło informacji historycznych}

Badanie okazów muzealnych, pochodzących nawet sprzed wielu tysięcy lat, to szansa na przybliżenie się do rozwiązania wielu nurtujących zagadnień, takich jak pochodzenie gatunków, choroby i epidemie wyniszczające ludzkość czy wędrówki ludów. Jedynym problemem w analizie jest metodyka, polegająca na izolacji DNA z zachowanych eksponatów. Niestety, wszystkie badania do tej pory opierały się na technice niszczącej, prowadzącej do nieodwracalnego uszkodzenia próbki. W wypadku preparatów muzealnych zakonserwowanych w płynach podczas standardowej destrukcyjnej izolacji DNA tkankę należy pociąć za pomocą np. skalpela, a następnie użyć jednej z metod homogenizacji - rozdrobnienia/roztarcia. Odcięcie fragmentu do badań powoduje mniejsze lub większe uszkodzenie eksponatu, czego muzealnicy bardzo nie lubią. Uzyskanie materiału genetycznego ze starych preparatów to wyzwanie dla współczesnej nauki, co dokładniej zostało opisane w pierwszej części tekstu. Pierwsze próby izolacji DNA z eksponatów muzealnych nastąpiły w 1985 roku. Dowiodły one, że z bloczków parafinowych, zawierających formalinę, w których utrwalono tkanki ludzkie, może być wyodrębniany materiał genetyczny ${ }^{9}$. Natomiast termin „,niedestrukcyjna” izolacja został użyty dopiero w 1999 roku podczas badań dotyczących uzyskania DNA z powierzchni otolitów bez ich zniszczenia ${ }^{10}$. Prawdziwym przełomem w izolacji DNA z tkanek były prace Shadi Shokralla z 2010 roku. Poddano wtedy analizie płyn konserwujący, a dokładnie alkohol, w którym zanurzone były larwy owadów. Stosując zestaw do komercyjnej izolacji DNA, wykonano eksperymenty z 40\% i 95\% roztworem etanolu - w którym znajdowały się

${ }^{8}$ D. Pluta, M. Tokarski, J. Siuta, A. Karpiewska, T. Dobosz, Muzealnictwo, medycyna i studencipionierski projekt zajęć dydaktycznych Katedry Medycyny Sadowej UM we Wroctawiu, „Opuscula Musealia" 2016, nr 24, s. 61-68.

9 Vide https://www.ncbi.nlm.nih.gov/pubmed/2992457 [dostęp: 19.03.2018].

${ }_{10}$ W.F. Hutchinson, G.R. Carvalho, S.I. Rogers, A nondestructive technique for the recovery of DNA from dried fish otholits for subsequent molecular genetic analysis, „Molecular Ecology” 1999, nr 8, s. 893-894. 
także starsze osobniki sprzed około 10 lat $^{11}$. Badanie zakończyło się sukcesem i potwierdziło tezę dyfuzji materiału genetycznego do płynu, w którym umieszczono zwierzęta. Powyższe osiągnięcia stały się inspiracją do podjęcia prób izolacji DNA z płynów konserwujących, użytych w celu zachowania eksponatów będących w posiadaniu Muzeum Medycyny Sądowej Uniwersytetu Medycznego we Wrocławiu. Ponadto na terenie Zakładu Technik Molekularnych Uniwersytetu Medycznego we Wrocławiu powstało kilka nowatorskich prac magisterskich z zakresu izolacji oraz badania kopalnego DNA (aDNA, ang. ancient DNA), które wraz z upływem czasu przeniknęło z tkanki do płynu konserwującego. W czasie badań prowadzonych w zakładzie wykorzystuje się proces rekonserwacji preparatów, podczas którego uzupełnia się lub wymienia roztwór utrwalający. Podczas tej czynności pobiera się w charakterze kontroli dodatniej wycinek tkanki oraz próbkę starego płynu do badań molekularnych, techniką niedestrukcyjną. Po zebraniu wystarczającej liczby tożsamych wyników można będzie uznać, że nowa technika, oparta na analizie płynu, jest w pełni wiarygodna i będzie mogła być stosowana z wyboru jako jedyna technika badań.

\section{Muzeum w służbie historii}

Ze względu na opisane powyżej uwarunkowania metoda nieniszczącej izolacji DNA jest w dalszym ciągu udoskonalana. Dotychczasowe badania wykazują, że największym problemem są uszkodzenia hydrolityczne, szczególnie intensywne w wypadku stosowania formaliny. Jak już wspomniano, związek ten indukuje także powstawanie wiązań krzyżowych, które uniemożliwiają poprawne przeprowadzenie powielania materiału genetycznego w reakcji łańcuchowej polimerazy. Trwają prace nad usunięciem tych wiązań tak, aby wyizolowany produkt był jak najlepszej jakości i mógł dostarczyć maksimum wiedzy genetyczno-historycznej na temat danej próbki. Zbadanie genów sprzed kilkudziesięciu, a nawet kilkuset lat to niezwykle cenna okazja do sięgnięcia metodami współczesnych technologii wstecz oraz poznania historii mokrych preparatów od zupełnie innej strony. Co bardzo ważne, podczas procedury w ogóle nie dochodzi do destrukcji cennych eksponatów. Dzięki takim eksperymentom muzealnictwo medyczne może zyskać nie tylko nową wiedzę, lecz także zainteresowanie szerszego grona odbiorców, a szczególnie młodych ludzi. Na terenie Uniwersytetu Medycznego we Wrocławiu, poza opisanym muzeum, znajdują się jeszcze dwa bardzo ciekawe miejsca - Muzeum Anatomii Prawidłowej oraz dermatologiczne Muzeum Mulaży. Profesor Tadeusz Dobosz został mianowany pełnomocnikiem Rektora ds. utworzenia Muzeum Medycyny wraz ze Szpitalem Muzeum oraz skatalogowania zasobów muzealnych. W ciągu najbliższego roku Muzeum Medycyny Sądowej ma zostać przeniesione do nowego, znacznie wygodniejszego lokum oraz unowocześnione. W planach jest także reorganizacja Muzeum Ginekologii

${ }^{11}$ S. Shokralla, G.A.C. Singer, M. Hajibabaei, Direct PCR amplification and sequencing of specimens' DNA from preservative ethanol, „BioTechniques” 2010, t. 48, nr 3. 
i utworzenie Muzeum Fantomów Medycznych oraz Muzeum Rektoratu ${ }^{12}$. Tego rodzaju sieć muzeów medycznych, połączonych w jedną ścieżkę dydaktyczną o długości ok. 1,5 km, przebiegająca przez piękny, XIX-wieczny Stary Kampus, z pewnością zapewni turystom wiele interesujących wrażeń, a nauczycielom dostarczy nowych możliwości organizowania lekcji na zewnątrz szkoły oraz udowodni, że muzea mogą być interesującym miejscem także do spędzania wolnego czasu.

\section{Podsumowanie}

Nieustanny rozwój genetyki molekularnej oraz nauk medycznych daje szansę dotąd mało dostępnemu Muzeum Medycyny Sądowej we Wrocławiu na zaistnienie na turystycznej mapie Wrocławia i regionu. Mamy nadzieję, że powiększenie zbiorów o krakowskie eksponaty przyczyni się do szybszej poprawy warunków lokalowych Muzeum Medycyny Sądowej. Możliwość nieinwazyjnych badań kopalnego materiału genetycznego to szansa na poznanie historii medycyny sądowej od innej strony. Pozwoli na poszerzenie wiedzy dotyczącej ówczesnych chorób czy patologii, weryfikację danych historycznych oraz porównanie uzyskanych informacji z aktualną wiedzą. Rozwijane metody sprawią, że eksponaty nie zostaną w najmniejszym stopniu uszkodzone oraz będą mogły służyć celom naukowym i dydaktycznym jeszcze przez wiele lat. Połączenie osiągnięć genetyki molekularnej oraz potencjału nowoczesnych technologii podczas organizacji muzeum to szansa na upowszechnienie i popularyzację muzealnictwa medycznego, zwłaszcza wśród młodych pokoleń.

\section{Bibliografia}

Gryglewski R.W., Zygmunt Laskowski i jego technika tworzenia preparatów anatomicznych, „Przegląd Lekarski” 2015, nr 72.

Hildebrand M., Anatomical preparations, Berkley, California 1968.

https://www.ncbi.nlm.nih.gov/pubmed/2992457 [dostęp: 19.03.2018].

Hutchinson W.F., Carvalho G.R., Rogers S.I., A nondestructive technique for the recovery of DNA from dried fish otholits for subsequent molecular genetic analysis, „Molecular Ecology” 1999, nr 8.

Korga A., Trudności w wykorzystaniu tkanek z archiwalnych bloczków parafinowych w badaniach ekspresji RNA, „Postępy Higieny i Medycyny Doświadczalnej” 2007, nr 61.

Krzywobłocki A., Dziesięć lat pracy konserwatorskiej w wojew. wrocławskim, „Ochrona Zabytków" 1955, nr 8(1), 28.

Medycyna Uniwersytecka we Wrocławiu. Zarys historii od 1945 roku, Wrocław 2011.

Pluta D., Tokarski M., Siuta J., Karpiewska A., Dobosz T., Muzealnictwo, medycyna i studenci-pionierski projekt zajęć dydaktycznych Katedry Medycyny Sądowej UM we Wroctawiu, „Opuscula Musealia” 2016, nr 24.

${ }^{12}$ M. Szwarc, Wizyty w tym miejscu szybko nie zapomnisz, „Gazeta Uczelniana Uniwersytetu Medycznego im. Piastów Śląskich we Wrocławiu” 2017, nr 11, s. 26-29. 
Podręczny słownik chemiczny, red. R. Hassa, J. Mrzigod, Katowice 2004.

Rozporządzenie Ministra Zdrowia z dnia 30 lipca 2009 r. w sprawie trybu i warunków przekazywania zwłok do celów naukowych.

Shokralla S., Singer G.A.C., Hajibabaei M., Direct PCR amplification and sequencing of specimens' DNA from preservative ethanol., „BioTechniques” 2010, t. 48, $\mathrm{nr} 3$.

Szwarc M., Wizyty w tym miejscu szybko nie zapomnisz, „Gazeta Uczelniana Uniwersytetu Medycznego im. Piastów Śląskich we Wrocławiu” 2017, nr 11.

Ustawa z dnia 1 lipca 2005 r., o pobieraniu, przechowywaniu i przeszczepianiu komórek, tkanek i narządów.

Wilemska K., Zieliński M., Jasińska M., Szynawa M., Kucharzewski M., Frederik Ruysch-życie i działalność medyczna, „Annales Academiae Medicae Silesiensis” 2012, nr 66. 